\section{Effects of Social Comparison, Travel Envy and Self-presentation on the Intention to Visit Tourist Destinations}

\author{
Danielle Fernandes Costa Machado ${ }^{1}$ \\ daniellefcm@gmail.com | (10) 0000-0002-5975-3248 \\ Paula Candida do Couto Santos ${ }^{1}$ \\ paulacoutosantos@gmail.com | (D) 0000-0002-4727-7627 \\ Mirna de Lima Medeiros ${ }^{2}$ \\ mirnadelimamedeiros@gmail.com | (1) 0000-0002-7198-9835
}

\begin{abstract}
Sharing travel experiences through social networks has become a very common practice today. Access and exposure to posted content can generate, in users, behavioral and emotional reactions capable of affecting their intention to travel. Based on this, the objective of the present work is to verify the effects of behavioral characteristics (social comparison, envy and self-presentation) on the intention to visit destinations, as displayed by users on social networks--more specifically, on Instagram. The study methodology consists of a survey applied online from May to June 2018 with Instagram users, in which we obtained 547 valid responses. For data analysis, we used descriptive statistics, factor analysis, and logistic regression to test and confirm the hypotheses of the presented theoretical model. The results indicate that envy and social comparison increase the odds of intention to visit a destination, with the strongest effect being related to the social comparison variable.
\end{abstract}

\section{KEYWORDS}

Social Networks, Travel Envy, Social Comparison, Self-presentation, Travel intention
${ }^{1}$ Universidade Federal de Minas Gerais, UFMG, Belo Horizonte, MG, Brasil

${ }^{2}$ Universidade Estadual de Ponta Grossa, Ponta Grossa, PR, Brasil

Received: 06/19/2020.

Revised: 09/03/2020.

Accepted: 10/19/2020.

Published Online: 03/30/2021.

DOI: http://dx.doi.org/10.15728/bbr.2021.18.3.4 


\section{INTRODUCTION}

The popularization of the internet, as well as information and communication technologies (ICTs), is responsible for changing society's habits and customs, intensifying access and the amount of information received by users and, consequently, influencing their purchase decision processes. The advance of these technologies is accompanied by the popularization of digital cameras, smartphones, and computers, along with other devices that facilitate the iconographic record of trips, allowing their rapid diffusion on social networks. More than just a representation of a place, tourist photography is full of personal meaning, and its sharing connects the traveler's self to the public (Lo \& Mckercher, 2015). According to Ferrari and Gândara (2015), travel photographs can be considered as one of the most precious memories for tourists, especially in a context in which they can be displayed as "trophies" to impress followers and friends on social networks.

Social networks intensify the exchange of information about destinations, attractions and tourist services and, at the same time, enhance the visibility of tourist experiences, mainly from the exposure of travel photographs (Machado, 2015; Lo \& Mckercher, 2015). Consequently, they are also responsible for generating changes in the consumption habits of travelers, allowing them to independently plan trips, share their tourist experiences in real time, do online reviews on used services and produce relevant content about visited destinations. Thus, social networks make it possible for ordinary travelers to exercise, to some extent, the role of digital influencers (Menéndez \& Vázquez, 2017). In this sense, the sharing of travel experiences on social networks plays an important role in forming the awareness, expectations, perceptions, attitudes, and behaviors of users (Narangajavan Kaosiri et al., 2017; Liu, Wu \& Li, 2018), in addition to enhancing the visibility of what they consume.

According to Liu, Wu and Li (2018), travel posts on social networks can easily trigger social comparisons between peers, since these networks provide a platform for self-presentation in which users tend to disclose positive aspects of themselves in order to transmit superiority and achieve social recognition (Vogel et al. 2014; Lim \& Yang, 2015). In this sense, individuals often engage in the creation and posting of content that seeks to produce a favorable personal image. Such contents are often associated with the display of consumer experiences that have a strong emotional and prestige appeal, including luxury cars, dining in refined restaurants, and trips to trendy, famous or paradisiacal destinations (Cheng \& Fu, 2019; Taylor \& Strutton, 2016). Furthermore, these shared travel experiences carry positive symbolic meanings, including professional achievements, wealth, status, and happiness in personal life. These positive meanings can stimulate social comparison and evoke feelings of envy (Kerr, Lewis \& Burgess, 2012; Van de Ven, Zeelenber \& Pieters, 2009). In turn, Belk (2011) points out that envy can stimulate aspirational consumption and, consequently, positively influence the purchase intention.

Self-presentation, therefore, enhances the social comparison processes that are triggered when people compare the received social notifications (such as, posts, newsfeeds, photos, etc.) to their own selves, and this, many times, can generate feelings of envy (Krasnova et al., 2010; Cheng $\& \mathrm{Fu}, 2019)$ that act as a trigger capable of affecting the behavioral intention of consumption (Cheng \& Fu, 2019). In the specialized tourism literature, Hajli, Wang and Tajvidi (2018) and Liu, Wu and Li (2019) point out that the feeling of travel envy has a positive and significant relationship with the intention of visiting a destination previously mentioned by friends on the social networks.

Based on those relationships pointed out in the literature, this study aims to answer the following question: Do social networks, by encouraging behaviors of social comparison, self-presentation 
and feeling of envy in their users, influence the intention to visit tourist destinations? Aiming to answer this problem, this research seeks to verify the effects of behavioral characteristics (social comparison, envy, and self-presentation) in the intention of visiting destinations displayed by users on social networks, more specifically, on Instagram. The choice of this social network is due to the fact that Instagram, despite not being the social network with the largest number of users (Facebook and Youtube lead the ranking), is attracting new users faster than Facebook's main site and has potential to exceed 2 billion users by 2023 (McCormic, 2018; Pew Research Center, 2019). Furthermore, considering the constructs to be analyzed in this research (self-presentation and envy), Instagram occupies a prominent position, as it is a social media focused on sharing images, where people post photos and show a little more of themselves or their daily life.

The sharing of travel experiences has become ubiquitous today (Liu, Wu \& Li, 2019). Understanding the motivations and effects generated by posting and viewing photographs on social networks is, therefore, fundamental to a better understanding of tourist behavior in the digital world. This understanding can help in planning and managing place marketing, based on the more rational and efficient use of social networks by destination marketing organizations. On the other hand, the academic discussion is recent and focuses on the importance of understanding the relationships between users, the subjective aspects, among other issues related to behavioral stimuli raised by social networks.

According to Liu, Wu and Li (2019), studies on the effect of envy on travel consumption intentions are scarce, with the majority of work on the topic focusing on analyzing online review websites (such as Tripadvisor), leaving a gap in specific studies regarding social networks such as Facebook and Instagram (Liu, Wu \& Li, 2019). Finally, no studies were found that address the constructs in question in the Brazilian context. We consulted the research repositories "CAPES Periodicals"; "Spell"; "ISI Web of Knowledge"; "Web of Science" and "Scopus" before and after completing this research, the last verification being in June 2020.

\section{THEORETICAL FOUNDATION}

\subsection{Social Media and Consumer Behavior}

According to Buhalis and Law (2008), since the 1980s, information and communication technologies have transformed tourism. In the first twenty years, the emphasis was on the adoption of technology itself and, from the 2000s onwards, there is a greater emphasis on communication based on the development of several tools that globally facilitate the interaction between different actors. In this scenario, not only do ICTs support the globalization of the sector, providing effective tools for suppliers to develop, manage, and distribute their offers, but also enable consumers to identify, personalize, and purchase tourism products, as well as collaborate with other consumers (Buhalis \& Law, 2008; Barbosa \& Medaglia, 2019). This context encourages an expressive flow of information, some of which can be decisive to arouse curiosity and interest in traveling (Marujo, 2008).

Among the various online options, social media present themselves with great strength and as something intrinsic to everyday life nowadays (Gumpo et al., 2020). People visit these websites for different reasons and behave differently in each of them, some of which have a specific focus (Whitty, 2008). Krasnova et al. (2010) mention that users' motivation to disseminate information on social media is mainly due to the convenience of maintaining and developing relationships and enjoying the platform. 
Peer communication on social media is particularly influential for travelers of the millennial generation, also known as the net generation, which comprises those born approximately between 1981 and 1999 (Liu, Wu \& Li, 2019). According to the authors, previous studies show that this generation of consumers is more technologically experienced and tends to rely on social media to search for information and make decisions. Parsons (2017), in turn, highlights that the influence on travel decisions among the younger age group is also due to their presence on the platforms. Liu, Wu \& Li (2019) suggest that research not restrict the sample, in order to find out if there is the same effect as was done in the research on screen, since age, frequency of use, and other demographic factors can influence the purchase intention.

User-generated content (UGC) on social media - photos, comments, narratives and stories - is increasingly critical for the travel and tourism industry, permeating all aspects of decision making, motivation, and experience of consumers (Taylor, 2020). This content produced by users can influence the entire travel process (before, during and after the visit). Before traveling, it is used as a source of information and can affect the expectation and intention to purchase; during the trip, it can affect the perceptions of the tourist experience, as well as generate the desire to produce experienced content (knowledge or experiences); and post-trip it can impact tourist satisfaction, future referrals, electronic word-of-mouth (eWOM) and intention of revisiting, for example (Narangajavana Kaosiri et al., 2019). The present study emphasizes the pre-visit stage, verifying the relationship of behavioral aspects, which are discussed below, in the intention of visiting tourist destinations.

\subsection{Self-Presentation}

Goffman (1959) presents the idea that self-presentation is an intentional and tangible component of identity, and that its aim is to make others accept the images that people claim for themselves. The author argues that people are like actors, acting as if they are on a stage presenting their positive aspects and the impressions they want to be reminded by.

People employ various self-presentation strategies, both during face-to-face and online interactions (Schlenker \& Pontari, 2000). Self-presentation refers to the value that users derive from the ability to improve their self-concept in relation to others through their online social networks (Krasnova et al., 2010). Therefore, individuals can be very selective in their online selfpresentations (Whitty, 2008). They tend to show their best self-image on social media platforms and, consequently, the posted content usually displays only the best part of their lives (Cheng $\& \mathrm{Fu}, 2019)$.

Krasnova et al. (2010) consider that, when receiving social notifications such as posts, newsfeeds, and photos from other people, individuals compare the user-generated content to themselves, and this comparison can stimulate envious feelings. As a result, most academic studies on the topic consider that envy plays a significant mediating role between self-presentation and travel intention. However, Hajli, Wang and Tajvid (2018) concluded that self-presentation also directly influences this intention. Despite that, such direct relationship between self-presentation and intention to visit has been little tested in the literature.

In order to contribute to this gap, and considering the different reactions to sensory and behavioral stimuli generated by social networks, we consider that users' posts are influenced by their peers' posts (Wang, Yu \& Wei, 2012). Thus, it is assumed that trips to coveted destinations activate aspirational motivations, making people more willing to improve their own status (reactive self-presentation) and, consequently, influencing their intentions to visit those destinations. Based on these considerations, the first research hypothesis of the present study is formulated: 
H1 - Self-presentation positively influences the intention to visit a tourist destination.

\subsection{Social Comparison}

Festiger (1954) was the pioneer researcher in studies on social comparison. According to the author, social comparison occurs when people compare their own characteristics and aptitudes to that of other people. It is assumed that people need to compare themselves with others so that, in this way, they gain a better understanding of themselves. The author considers that there are two types of comparisons, that of opinion and that of skills. The purpose of social opinion comparison is to learn about facts and norms, which are the basis for individuals to position themselves in a social context. Social skill comparison necessarily involves a value judgment--that is, who is better and who is worse.

For Wood (1996), the theory of social comparison is based on the process of thinking about information regarding other people in relation to ourselves. Lee (2014) believes that social comparison serves to reduce uncertainty regarding values, problems and opinions. Collins (1996) considers that such comparisons may have repercussions on self-assessment, and may be associated with positive or negative feelings. De Botton (2004) adds that the concern with social status and social comparisons is determined by the desire to receive some evidence that we are loved or respected by those who are important to us. Suls and Wheeler (2000), on the other hand, state that comparing ourselves with other people and evaluating someone's relative position influences a person's self-concept, aspiration level and feelings of well-being.

Social comparison can inflate or decrease self-concept depending on the direction of the comparison (Taylor, 2020). In the descending social comparison, the person to whom individuals compare themselves to is judged to be inferior, which can raise their self-image. In the upward social comparison, the object of comparison is judged to be superior, which can be inspiring, threatening, or both. (Taylor, 2020; Liu, Wu \& Li, 2019). In the upward comparison, the potential negative effects are: self-assessment and decreased subjective well-being, depression (Liu, Wu \& $\mathrm{Li}, 2019)$ and aversion towards those subjects who are envied (Belk, 2011). The positives refer to the motivation to maintain or improve a positive sense of self ( $\mathrm{Liu}, \mathrm{Wu} \& \mathrm{Li}, 2019$ ).

Mussweiler, Rüter and Epstude (2006) believe that the processes of social comparison are always triggered when people are confronted with information about other people. In this sense, social networks enhance this sharing of information and impressions and, consequently, stimulate the behavior of social comparison among its users. When browsing other people's information, people tend to associate it with themselves and compare themselves with others (Cheng \& Fu, 2019). With the popularization ofsocial media, social comparison has been more ubiquitous among people (Sabatini \& Sarracino, 2019). People "follow" other users, keeping up with their lives and, deliberately or unconsciously, monitoring how they present themselves, what they do and how they interact (Lee, 2014; Sabatini \& Sarracino, 2019).

When social media is used for social comparisons, consumers often compare their real lives with an ideal of other people's lives, often deliberately constructed, as social media users often highlight positive aspects of themselves (Taylor, 2020 ; Lo \& McKercher, 2015; Whitty, 2008). Thus, when individuals evaluate themselves using these heuristics, they are more likely to perceive the direction of social comparison as upward, which can lead to increased levels of envy (Taylor, 2020). The upward social comparison, therefore, happens when the subject perceives others as being superior. Consequently, this type of comparison can boost aspirational consumption (that is, consumption driven by aspirations of social status) as a way of elevating a positive sense of self. Considering this process, it is believed that travel experiences shared on social networks stimulate 
upward social comparison and, consequently, influence the intention to visit for aspirational reasons. Thus, the second hypothesis of our research is presented:

H2 - Social comparison positively influences the intention to visit a tourist destination.

\subsection{EnVy In Social Networks}

According to Marques, Cavalcante and Ferraz (2017), envy, besides being a universal feeling, is also timeless and part of the psychic structure of the human being, interfering in our culture and way of organization. According to the authors, the feeling of envy is a social emotion and happens exactly due to the interaction between individuals, occurring between the envious and the envied. If people did not compare themselves to others, there would be no envy (Belk, 2011). The envy literature points out that it can be positive (benign) or negative (malignant) depending on the experiences, ideas and actions of individuals, being able to influence the social relationships and actions of individuals, including their buying behavior.

For authors who conceptualize envy through negative bias, the social interaction that the envious person establishes with the envied person is based on destructive thoughts and hostility. For Parrot and Smith (1993) envy is "something that arises when a person lacks another's superior quality, achievement, or possession and either desires it or wishes that the other lacked it". For Spinoza (1999), envy can be understood as a hate that can affect men, making them unhappy with the happiness of others and, even on the contrary, making them happy with the unhappiness of others. Contrary to the thoughts of envy as something negative, some authors consider that, although envy is an unpleasant emotion, it can induce a positive reaction after being triggered (Cheng \& Fu, 2019). Benign envy is associated with the behavioral tendency to improve oneself, with aspirational consumption and hard work, mirroring others (Belk, 2011; Van de Ven, Zeelenberg \& Pieters, 2011). Crusius and Mussieler (2012) affirm that envy motivates people to improve their own position, stimulating consumption. In turn, Van de Ven, Zeelenberg and Pieters (2011) suggest that benign envy can lead consumers to pay a higher price (premium) for the desired products belonging to the envied target.

The feeling of envy is believed to generate an increase in the intention to visit places or purchase material goods. Lin, Van de Ven \& Utz (2018) found that experiential purchases (such as travel) exposed on social networks causes more envy than material purchases. In the same direction, Taylor and Strutton (2016), Liu, Wu and Li (2019) and Cheg and Fu (2019) believe that people become prone to conspicuous consumption, influenced by others on social networks. Hajli, Wang and Tajvid (2018) state that sharing photos and posts about tourist destinations on social networks can act as a trigger capable of arousing feelings of envy in users, and may influence the intention to visit the portrayed destinations. In addition, Baker and Crompton (2000) point out that travelers' intention to visit a tourist destination is considered an effective indicator of their future travels. Based on these postulations, we present our third research hypothesis:

H3 - Travel envy on social media positively influences the intention to visit a tourist destination.

\section{METHODOLOGY}

This study is characterized by being an exploratory quantitative research whose main objective is to verify the effects of behavioral characteristics (social comparison, envy, and self-presentation) in the intention of visiting destinations displayed by users on social networks, more specifically, on Instagram. 
The scales used in the research form to measure theoretical constructs are based on the previous study carried out by Hajli, Wang and Tajvidi (2018) to examine the antecedents and consequences of travel envy on Facebook. The authors themselves recommend that new studies need to be developed in order to test the research instrument on other social media platforms. That is one of the reasons that leads this research to test the scales in the context of the social network Instagram. To this end, the scales were initially translated, and then underwent reverse translation by a specialist (Costa, 2018).

The online questionnaire was applied via Google Forms and was divided into two sessions. The first contains questions related to the respondents' individual characteristics and the second, questions related to behavioral characteristics related to self-presentation, social comparison and envy. In this second module, the questions are measured using a Likert-type scale, which ranges from 1 (strongly disagree) to 7 (strongly agree).

Data collection took place between May 11 and June 2, 2018. The online questionnaire was made available on the Google Forms platform and its access link was sent by email and social networks, following the method of data collection by Virtual Snowball. According to Costa (2018), the viral snowball method consists of sending a questionnaire for a specific group of social network users and asking them to pass on the search tool to others in their network. In this way, it is possible to obtain a self-generated sample based on sharing the form through the collaboration of respondents.

The primary respondents to the survey were selected using the non-probabilistic accessibility sample technique (Babbie, 2001) and, therefore, the profile of the participants cannot be generalized.

In order to operationalize the theoretical constructs, confirmatory factor analysis is used to confirm that the dimensions found correspond to the expected structure of the tested constructs and theoretical variables. The method used is Principal Component Analysis, which allows limiting the number of variables based on the determination of common latent factors (Corrar et al., 2012; Fávero et al., 2009). As expected, the variables are grouped in the factors proposed by Hajli, Wang and Tajvidi (2018) demonstrating that the scale is adequate for measuring the suggested constructs, as expressed in table 1 :

Table 1

Descriptive statistics resulting from Factor Analysis

\begin{tabular}{|c|c|c|c|c|}
\hline \multicolumn{5}{|c|}{ Measurement of constructs } \\
\hline Factors & Variables & Eigenvalues & \% Variance & Loadings \\
\hline \multirow[t]{3}{*}{$\begin{array}{l}\text { Social } \\
\text { Comparison }\end{array}$} & $\begin{array}{l}\text { COM1: I tend to compare myself with the people I } \\
\text { follow regarding the posts we show on Instagram }\end{array}$ & 3,379 & 67,573 & ,826 \\
\hline & $\begin{array}{l}\text { COM2: I tend to pay attention to how I do things } \\
\text { compared to what other people do on Instagram }\end{array}$ & & & ,833 \\
\hline & $\begin{array}{l}\text { COM3: I tend to compare the things that people } \\
\text { who I follow do and post on Instagram with what } \\
\text { others are doing and posting. }\end{array}$ & & & ,811 \\
\hline
\end{tabular}


Table 1

Cont.

\begin{tabular}{|c|c|c|c|c|}
\hline \multicolumn{5}{|c|}{ Measurement of constructs } \\
\hline Factors & Variables & Eigenvalues & $\%$ Variance & Loadings \\
\hline & $\begin{array}{l}\text { COM4: I usually compare how well I do things on } \\
\text { Instagram in relation to the people I follow }\end{array}$ & & & ,848 \\
\hline & $\begin{array}{l}\text { COM5: I usually compare how I stand out socially } \\
\text { (e.g., popularity) in relation to other people on } \\
\text { Instagram }\end{array}$ & & & ,791 \\
\hline \multirow[t]{5}{*}{$\begin{array}{l}\text { Travel Envy } \\
\text { on Social } \\
\text { Networks }\end{array}$} & $\begin{array}{l}\text { ENV1: In general, I find that most people I follow } \\
\text { on Instagram have a better life than mine. }\end{array}$ & 3,055 & 61,100 & ,751 \\
\hline & $\begin{array}{l}\text { ENV2: I believe that travel photos posted by people } \\
\text { I follow on Instagram get more likes than mine }\end{array}$ & & & ,638 \\
\hline & $\begin{array}{l}\text { ENV3: Somehow, I feel uncomfortable when I } \\
\text { see how wonderful are the travel photos posted by } \\
\text { some people I follow on Instagram. }\end{array}$ & & &, 854 \\
\hline & $\begin{array}{l}\text { ENV4: I feel uncomfortable when I realize the } \\
\text { popularity (eg, likes, shares, number of followers) } \\
\text { of the people I follow who post travel photos on } \\
\text { Instagram }\end{array}$ & & &, 834 \\
\hline & $\begin{array}{l}\text { ENV5: Somehow, I feel uncomfortable when I see } \\
\text { on Instagram how much the people I follow travel }\end{array}$ & & &, 812 \\
\hline \multirow[t]{3}{*}{$\begin{array}{l}\text { Self- } \\
\text { Presentation }\end{array}$} & $\begin{array}{l}\text { SP1: I try to make a good impression on my } \\
\text { followers on Instagram }\end{array}$ & 2,185 & 72,848 &, 886 \\
\hline & $\begin{array}{l}\text { SP2: I try to present myself in a favorable way to } \\
\text { my followers on Instagram }\end{array}$ & & & 918 \\
\hline & $\begin{array}{l}\text { SP3: Instagram allows me to show my best qualities } \\
\text { to my followers }\end{array}$ & & & ,746 \\
\hline \multirow[t]{2}{*}{$\begin{array}{l}\text { Destination } \\
\text { Visit Intention }\end{array}$} & $\begin{array}{l}\text { DVI1: If I get the chance to travel, I intend to } \\
\text { travel to destinations mentioned by people I follow } \\
\text { on Instagram }\end{array}$ & 1,700 & 85,012 & 922 \\
\hline & $\begin{array}{l}\text { DVI2: When I plan a trip, the likelihood of me } \\
\text { visiting destinations mentioned by people I follow } \\
\text { on Instagram is high. }\end{array}$ & & & 922 \\
\hline
\end{tabular}

Extraction Method: Principal Component Analysis

Source: Research data.

For methodological reasons, the construct of intention to visit the destination is dichotomized, that is, the continuous variable generated by the analysis of main components is recoded between 0 and 1 , where 0 represents all values below the median ( $=$ not having intention to visit ), and 
1 (= having the intention to visit the destination) represents all values above the median. Thus, the visit intention construct takes on a qualitative meaning defined arbitrarily by the authors through the median.

Then, the relationships are tested according to the Theoretical Model (Figure 1) below. It should be noted that the individual characteristics were not discussed in the theoretical model, but are used in statistical modeling as control variables.

BEHAVIORAL

CHARACTERISTICS

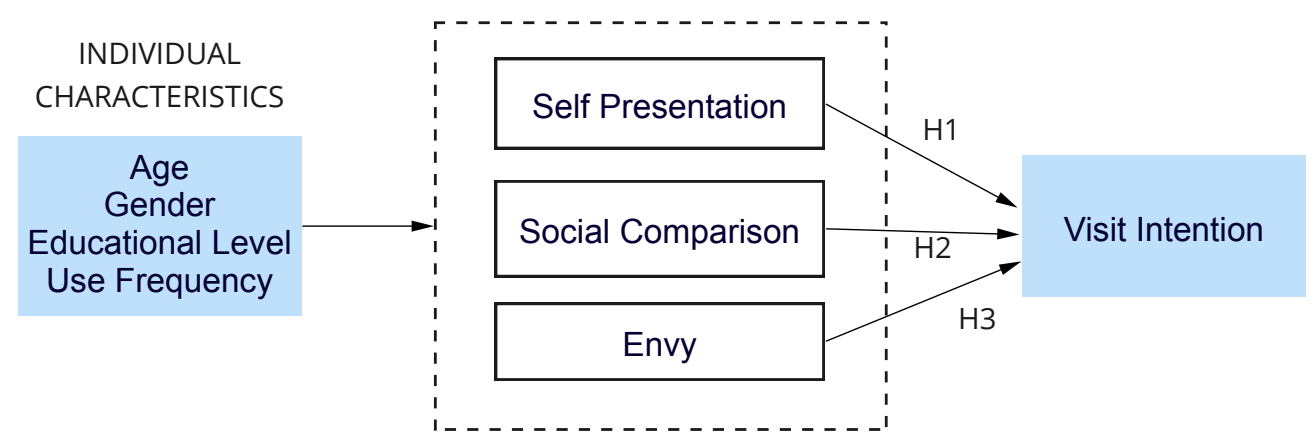

Figure 1. Research model

Source: Own elaboration.

For data treatment, the software Statistical Package for the Social Sciences (SPSS), modules of descriptive statistics, factor analysis, and logistic regression are used.

\section{RESULTS AND DISCUSSION}

An initial characterization of the sample profile indicates the relatively higher participation of women (75\%) compared to men (25\%). Most respondents are between 20 and 30 years old $(62.5 \%)$, and have at least an incomplete higher education (90\%). Regarding the frequency of access to Instagram, 77\% said they access digital media several times a day, according to data in Table 2 below. The 20 to 30 age group is considered to be young consumers by Gumpo et al. (2020). According to the authors, the social network Instagram has great popularity precisely with the public of this group. Furthermore, recent studies indicate that the influence of social networks on consumer behavior is especially significant for the Millennial generation, who is more prone to social comparison and, consequently, more likely to feel envy when exposed to the posts of their social media colleagues (Elejalde-Ruiz, 2015; Khanna, 2016). 
Table 2

Descriptive statistics for individual variables

\begin{tabular}{|c|c|c|c|}
\hline Variables & Description & Frequency & Percent \\
\hline \multirow[t]{2}{*}{ Gender } & Male & 137 & $25 \%$ \\
\hline & Female & 410 & $75 \%$ \\
\hline \multirow[t]{8}{*}{ Educational Level } & $\begin{array}{l}\text { Incomplete elementary } \\
\text { school }\end{array}$ & 2 & $0,2 \%$ \\
\hline & $\begin{array}{l}\text { Complete primary } \\
\text { education }\end{array}$ & 8 & $0,8 \%$ \\
\hline & Incomplete high school & 5 & $1 \%$ \\
\hline & Complete high school & 43 & $8 \%$ \\
\hline & $\begin{array}{l}\text { Incomplete higher } \\
\text { education }\end{array}$ & 188 & $34 \%$ \\
\hline & $\begin{array}{l}\text { Complete higher } \\
\text { education }\end{array}$ & 151 & $28 \%$ \\
\hline & Incomplete graduate & 48 & $9 \%$ \\
\hline & Complete graduate & 102 & $19 \%$ \\
\hline \multirow[t]{6}{*}{ Instagram use intensity } & Rarely & 24 & $4 \%$ \\
\hline & Once a month & 7 & $1 \%$ \\
\hline & Many times a month & 19 & $4 \%$ \\
\hline & Many times a week & 24 & $4 \%$ \\
\hline & Once a day & 55 & $10 \%$ \\
\hline & Many times a day & 418 & $77 \%$ \\
\hline
\end{tabular}

Source: Research data.

Regarding the behavioral variables (social comparison, envy and self-presentation), a descriptive statistical analysis of the values found for the sample is also performed. Table 3 shows the median values for each construct, as well as the asymmetry and kurtosis indices. We choose to present the median values, as the median offers a better idea of a typical value since it is not as distorted by extremely high or low values as the average of the data. Table 3 also shows the indices of asymmetry and kurtosis to meet the data normality criterion (Marôco, 2010).

In general, according to table 3, the sample has three particular characteristics for each construct group. In the first group, social comparison, the median observed is 3 for almost all variables, except for the first one, whose median value is 4 . For the set of variables that make up the construct related to envy, the median values observed are lower. This finding is congruent with that of Souza et al. (2018) who, in their study, point out that the social media Instagram does not arouse the feeling of envy in its users with regard to travel consumption. Finally, for the construct that represents self-presentation, the opposite is observed, that is, the median values are higher, with two of the three variables evaluated having a median equal to 5 . The data in Table 3 allows us to infer that respondents in the sample have a strong tendency to use Instagram to create a favorable image of themselves. This data corroborates Taylor (2020), Lo \& McKercher (2015) and Whitty (2008) regarding the deliberate exposure of positive aspects of oneself on social networks. On the other hand, contrary to expectations, travel jealousy does not seem to be a recurrent feeling among the subjects in the sample, since the values related to the "discomfort" resulting from the posts of others are the lowest ascertained. 
Table 3

Descriptive statistics of the Social Comparison, Envy and Self-Presentation scales

\begin{tabular}{lccccc}
\hline & Median & Kurtosis & $\begin{array}{c}\text { Std. Error of } \\
\text { Kurtosis }\end{array}$ & Minimum & Maximum \\
\hline COM 1 & 4 & $-1,085$ &, 209 & 1 & 7 \\
COM 2 & 3 & $-1,025$ &, 209 & 1 & 7 \\
COM 3 & 3 & $-1,046$ &, 209 & 1 & 7 \\
COM 4 & 3 & $-1,103$ &, 209 & 1 & 7 \\
COM 5 & 3 & $-1,287$ &, 209 & 1 & 7 \\
ENV 1 & 3 & $-1,140$ &, 209 & 1 & 7 \\
ENV 2 & 4 & $-1,382$ &, 209 & 1 & 7 \\
ENV 3 & 2 &,- 107 &, 209 & 1 & 7 \\
ENV 4 & 1 & 1,163 &, 209 & 1 & 7 \\
ENV 5 & 2 &,- 740 &, 209 & 1 & 7 \\
SP 1 & 5 & $-1,304$ &, 209 & 1 & 7 \\
SP 2 & 5 & $-1,144$ &, 209 & 1 & 7 \\
SP 3 & 4 & $-1,055$ &, 209 & 1 & 7 \\
\hline
\end{tabular}

Source: Research data.

For purposes of illustration, the boxplot graph below (figure 2) analyzes and compares the variation of the study variables (social comparison, envy and self-presentation) between respondents who do not intend to visit the destination (represented by group 0 ) and those who have intended to visit (represented by group 1). As can be seen, in the sample in question, the median of subjects who intend to travel is positive for the three aspects: comparison, envy and self-presentation. While in subjects who have no intention of visiting, these aspects are negative for social comparison and envy and very close to nullity in the case of self-presentation. It should be noted that, in the case of absence of visit intention, there are several outliers in relation to envy.

After presenting the descriptive statistical analysis of the data, a logistic regression analysis is performed to test and confirm the hypotheses of the theoretical model presented. As explained in the methodology, after the recoding, the dependent variable "intention to visit" is transformed into a dummy variable, assuming that 0 means "not having the intention to visit the destination" and 1 means "having the intention to visit the destination".

The present study seeks to evaluate the behavioral characteristics (independent variables) that can affect the intention to visit a destination (dependent variable). Thus, all variables considered in the model are controlled with each other. As a series of independent variables is used, a model is adopted using multiple logistic regression analysis. The measure of association calculated from this logistic model is the odds ratio, obtained by comparing respondents who differ only in the attribute of interest, keeping the values of the other variables constant.

Table 4 below shows the results of the regression analysis. Then, the results are presented and discussed. 
BBR

18

308

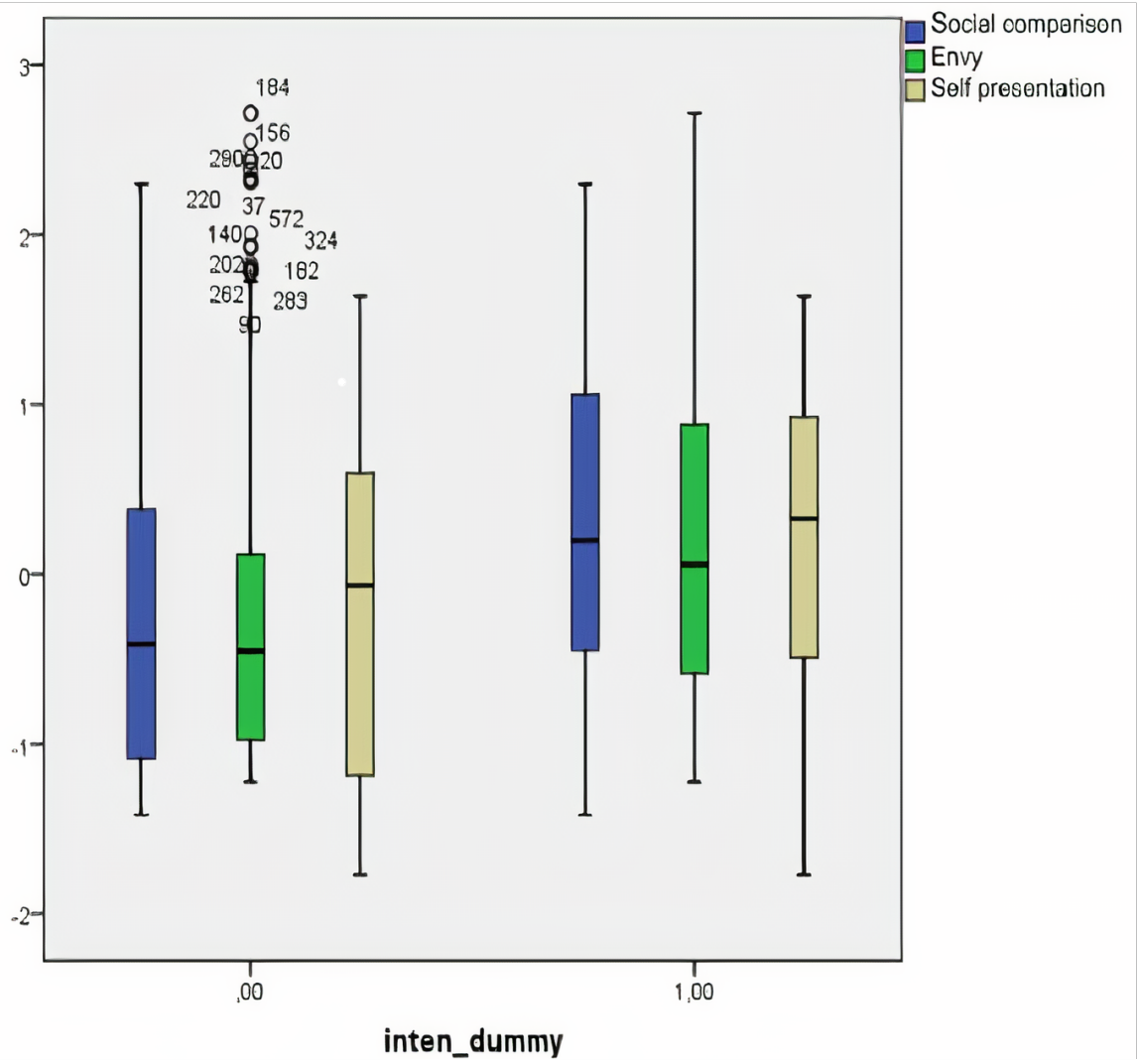

Figure 2. Comparative boxplot graph: Intention to visit the destination Source: Research data.

Table 4

Odds ratio of the intention to visit the destination determinants

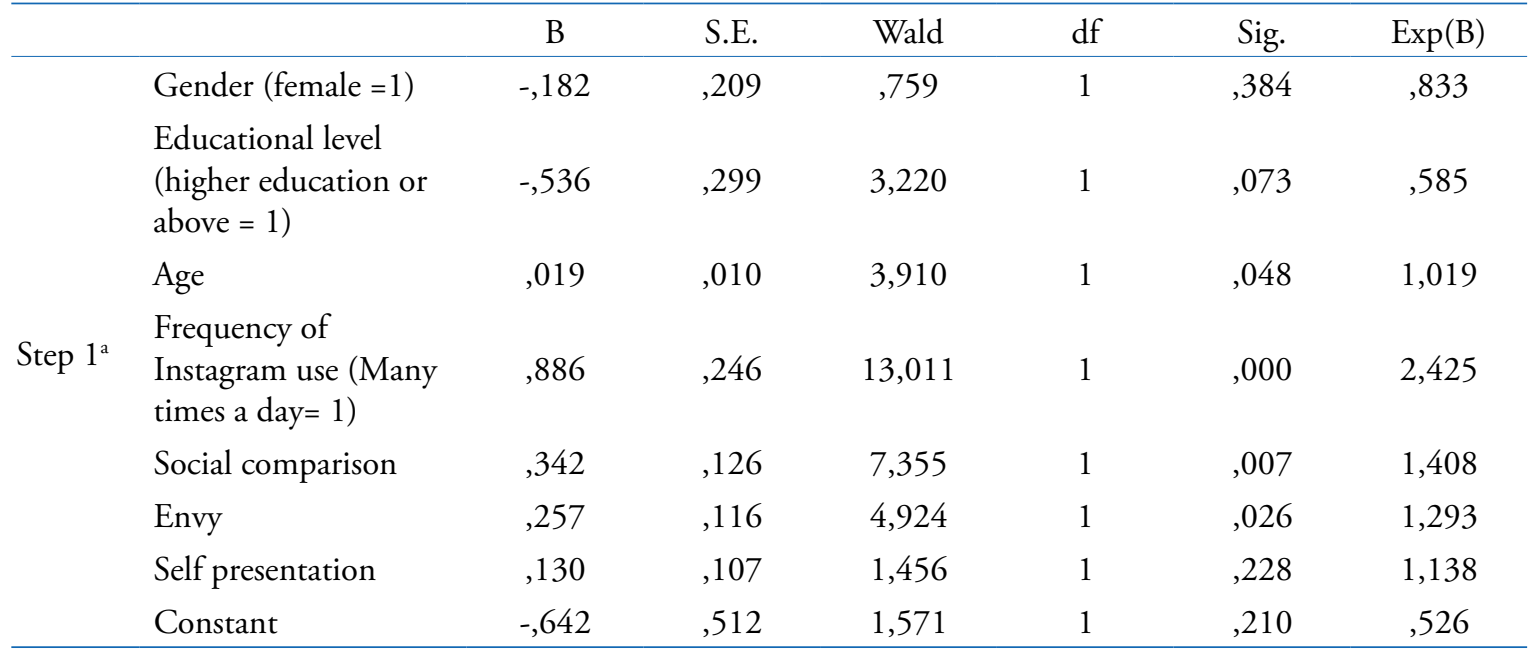

Variable(s) entered on step 1: female, higher, age, intfreq, COM, Envy, SP.

Source: Research data. 
As shown in Table 4, in the group of individual variables, only the variables age and frequency of Instagram use are statistically significant at the 5\% significance level (represented by the value below 0.05 in the table's "Sig." column). According to the data, the increase in the respondent's age by one year increases the odds ratio of intention to visit by $0.19 \%$. As the sample is composed mainly of members from the age group who, according to Gumpo (2020), adhere more to this social media, understanding this relationship of increasing age with the intention to buy can be a complement to what Parsons (2017) points out: that Instagram affects the younger generation and their travel decisions due to their presence on the platforms. In relation to this presence, data on the frequency of Instagram use reveals that those people who use Instagram several times a day increase their odds of visiting the destination by $142.5 \%$. Therefore, the longer the user spends browsing the social network, the more likely they are to be exposed to some type of content related to tourist travel, and this positively affects their intention to visit the displayed destinations. In addition, the results of Gumpo et al. (2020) suggest that the more Instagram users appreciate the app, the more they are likely to be influenced in their intentions to visit a tourist destination.

Regressions related to behavioral constructs reveal that only social comparison and envy are statistically significant. Thus, the data demonstrate that the increase of one unit on the scale of the social comparison construct increases the odds ratio of visiting the destination by $40.8 \%$, that is, the more people compare, the more likely it is to influence their visit intention. In the case of the envy construct, the odds ratio is increased by $29.3 \%$ in the event of a variation of one unit on the scale. The finding corroborates the results found in previous studies that indicate that envy, especially benign envy, influences consumption intentions and behavior, either to improve self-presentation or to decrease negative emotions through reactive consumption (Cheng \& Fu, 2019; Liu, Wu \& Li, 2019; Lin, Van de Ven \& Utz, 2018; Belk, 2011; Van de Ven, Zeelenberg \& Pieters, 2011).

Regarding self-presentation, contrary to the result found by Hajli, Wang and Tajvid (2018), it is not possible to confirm the hypothesis that it directly affects the intention to visit a destination. The incongruity in the results indicates that this construct needs to be better explored in the literature. Since self-presentation involves complex social games to impress the public and there is a reactive symbiosis of behaviors between the individual and the other, it is considered that other variables, such as strength of bonds, identification between peers and traits of personality should be tested as control variables to better understand these effects. Nevertheless, the analysis of the descriptive statistics of the present study reveals that the engagement of the sample users in their self-presentation is quite recurrent, since this construct has the highest medians among all dimensions considered in the study (as can be seen in figure 2). Therefore, the study points to the relevance of Instagram as a tool for managing users' impressions, revealing the concern of individuals to make a good impression and show their qualities on the social network, for example, from posting well-produced personal photos and revealing the consumption of products with a strong appeal of social status, including travel and tourist destinations. The data corroborate Goffman's (1959) theory that presents the idea that people are like actors, as if they were on a stage presenting their positive aspects and the impressions they want to be highlighted. Based on the results, it is possible to prove that Instagram is intentionally used by the survey respondents to promote their self-presentation, demonstrating that the social network acts as a stage for its users to act, showing the best of themselves. 


\section{FINAL CONSIDERATIONS}

From the obtained results, it is possible to verify that, among the analyzed behavioral characteristics (self-presentation, envy and social comparison), only the social comparison and envy variables are statistically significant in terms of the intention to visit the tourist destination. The data indicates that the increase of one unit in the scale of social comparison increases the chances of intention to visit the destination in $40.8 \%$. In the envy variable, there is an increase of $29.3 \%$.

Regarding the profile of the Instagram user, it is possible to evaluate that, among the individual characteristics (gender, age, education, and intensity of use of Instagram), only the variables age and intensity of use show statistically significant relationships in the intention of visiting destinations featured on Instagram. The study points out that, with each year of increase in the respondent's age, the chance of visiting the tourist destination increases by $0.19 \%$. Regarding the variable frequency of Instagram use, it is observed that those who use the platform several times a day are $142.5 \%$ exposed to the increased chance of visiting the destination, that is, the longer the user uses the platform, the greater the chance of positively increasing the intention to visit the shown destinations.

In addition to the objectives of this work, it is also identified that the travel content posted on the social network, contrary to expectations, does not arouse strong feelings of envy in the studied sample. Souza et. al (2018), in a study on envy in social networks, point out difficulty in verifying the sincerity of the answers on this question. It is considered, therefore, that the result of our research may have suffered interferences from the respondents' manipulation in ostensibly assuming their real feelings, since the social representation about the concept of envy imputes negative and sinful connotations to it. Therefore, envy emerges as a theoretical concept that imposes additional challenges on researchers who venture to estimate it, and such difficulties are not restricted to studies using quantitative methods. However, we consider that this analysis effort is imperative, as it is a universal and common feeling that can influence the choices and the decision-making processes of consumers.

In our research we are able to prove that the content posted on social networks is a source of envy, however, it is considered that this effect may be underestimated due to the discussion held here. Despite this, it is possible to prove that travel posts can stimulate the feeling of envy, affecting the Instagram users' intention to visit. Future studies may use mixed methods to try to find more precise ways of measuring envy, such as, for example, the adoption of qualitative projective techniques before the quantitative stage is carried out.

Although our work is inspired by the research by Hajli, Wang and Tajvidi (2018), we seek to contribute to the advancement of previous research by testing the effects of study variables on a different social network platform (in the original study, the authors investigated Facebook users, instead of Instagram, and left it as a suggestion for future research that this approach be carried out). In addition, we use a distinct statistical analysis method (structural equations $\mathrm{X}$ logistic regression) and focus on testing the model in a sample composed exclusively of Brazilians. Unlike the study by Hajli, Wang and Tajvid (2018), the methodological strategy adopted in our research evaluates the direct effect of the set of independent variables on the response variable corresponding to the intention to visit a tourist destination. When using the logistic regression model to estimate the odds ratios, the intervening effect of the variable envy was not modeled. However, this does not invalidate our results, as these were obtained through another methodological approach that is guided by scientific rigor throughout the process of preparing and carrying out the research. The exploratory character of our study has the challenge of incorporating theoretical and methodological similarities found in other previous investigations, but it does 
not consist of an integral replication of these researches. Thus, it is intended to understand and investigate other realities and contexts, as well as to propose new methodologies for analyzing the investigated issues.

While Hajli, Wang and Tajvid (2018) found that the direct effect of social comparison is not significant for the intention to visit, but is significant for self-presentation, we find a statistically significant relationship between intention to visit and social comparison, but not for selfpresentation. In this sense, it is considered that the differences in the researches' findings, instead of meaning a refutation of the previous studies, indicates, in reality, that new investigations must be conducted, mainly because those are behavioral variables that involve complex human interactions in the digital environment and are extremely volatile and dynamic. This reinforces the need for such relationships to be tested in future research in order to provide a better understanding of the profile of social networks users and their consumption behavior regarding traveling.

It is important to emphasize that the present work has some limitations. In this sense, we highlight that the collected sample is not representative of the population, since a sample for convenience was carried out, showing biases related to the profile of the interviewees, for example, high rate of respondents with complete and incomplete higher education and predominance of female respondents aged between 20 and 30 years old. We suggest for future researches to apply the empirical model to other countries, aiming to understand and measure the difference of the Instagram platform for different peoples and cultures, since seminal studies indicate that the country's culture variable influences differently the behavioral uses and responses of social network users (Mooji \& Hofstede, 2011).

Finally, answering the central question of this study: "Do social networks, by stimulating behaviors of social comparison, self-presentation and envy in their users, influence the intention to visit tourist destinations?", we conclude that the feeling of travel envy on social networks isn't very recurrent among respondents in the sample. Despite this, it is possible to prove that envy and social comparison have a direct positive effect on the intention to visit tourist destinations, corroborating two of the three research hypotheses that we investigated.

In addition to the academic contribution, the present work has important managerial implications. The results found show that destination marketing organizations (DMOs) need to adapt their management and promotion efforts to understand the logic of the evolution of the market as a social process, in which it is essential to discuss the participation of tourists in the process of communication through the sharing of travel experiences and the co-creation of content (Lourenção et al., 2020).

By taking into account the proven hypotheses that envy and social comparison have a direct positive effect on the visit intention, destination marketing efforts (whether from government or private companies) can direct their attention not only to generating official content, but also to content (and interactions) generated by users in a combined way. Marketing management can be adopted with a focus on making the tourist-consumer a protagonist in the creation and dissemination of content about the destination, through, for example: a) interactions and engagement with users in order to encourage them to share their travel experiences on social networks; b) use of photographs produced by tourists for the elaboration of tourism communication; c) production of content that evokes attributes of a certain lifestyle or that stimulates the target audience's desire for status (encouraging conspicuous consumption); d) other strategies that allow the exposure of the various visitors and their interaction with their peers.

Finally, it should be noted that the pandemic scenario of COVID-19, experienced in the year 2020 , is bringing several disruptions in consumption whose subsequent maintenance is still 
unknown (Sheth, 2020). Among these changes, there is a strong increase in the "digitization" of several social and commercial issues (Coelho \& Mayer, 2020; Gössling et al., 2020). Thus, there is still a lot of conceptual and empirical space to explore the effects of relationships on virtual social networks regarding the intention to visit destinations. This is especially relevant in the current context of crisis and uncertainty. In a scenario of so many restrictions and reduced mobility, travel has become, even if temporarily, a scarce resource. If in the very recent past, literature considered that luxury destinations aroused social comparison and envy, what will be the new destinations that are the targets of other people's greed? More than ever, understanding this tangle of feelings and behavior stimulated by social networks seems to be an indispensable contribution of the academy for thinking about the direction and future of tourism.

\section{REFERENCES}

Babbie, E. (2001). Métodos de Pesquisas de Survey. Belo Horizonte: Editora UFMG.

Baker, D.A., \& Crompton, J. L. (2000). Quality, satisfaction and behavioral intentions. Annals of Tourism Research, 27(3), 785-804. http://doi.org/10.1016/S0160-7383(99)00108-5

Barbosa, D. P., \& Medaglia, J. (2019). Tecnologia digital, turismo e os hábitos de consumo dos viajantes contemporâneos. Marketing \& Tourism Review, 4(2), 1-33. http://doi.org/10.29149/ mtr.v4i2.5394

Belk, R. (2011). Benign Envy. Academy of Marketing Science Review, 1(1), 117-134. http://doi. org/10.1007/s13162-011-0018-x

Botton, A. (2004) Status anxiety. New York: Penguin.

Buhalis, D., \& Law, R. (2008). Progress in information technology and tourism management: 20 years on and 10 years after the Internet-The state of e Tourism research. Tourism Management, 29(4), 609-623. http://doi.org/10.1016/j.tourman.2008.01.005

Buunk, A. P., \& Gibbons, F. X. (2006). Social comparison orientation: A new perspective on those who do and those who don't compare with others. In S. Guimond (Ed.). Social comparison and social psychology: Understanding cognition, intergroup relations, and culture (pp. 15-32). New York, NY, US: Cambridge University Press.

Chen, Y. C., Shang, R. A., \& Li, M. J. (2014). The effects of perceived relevance of travel blogs' content on the behavioral intention to visit a tourist destination. Computers in Human Behavior, 30, 787-799.

Cheng, H. H., \& Fu, T. J. (2019). Exploring the antecedents of conspicuous consumption and posting behavior of conspicuous consumption on Instagram. Proceedings of the 2019 10th International Conference on E-Business, Management and Economics (ICEME 2019), 229-233. http://doi. org/10.1145/3345035.3345072

Coelho, M. F., \& Mayer, V. F. (2020). Gestão de serviços pós-covid: o que se pode aprender com o setor de turismo e viagens. Revista Eletrônica Gestão \& Sociedade, 14(39), 3698-3706. http://doi. org/10.21171/ges.v14i39.3306

Collins, R. L. (1996). For better or worse: the impact of upward social comparison on self-evaluation. Psychological Bulletin, 119(1), 70-94. http://doi.org/10.1037/0033-2909.119.1.51

Costa, B. R. L. (2018) Bola de Neve Virtual: O uso das redes sociais virtuais no processo de coleta de dados de uma pesquisa científica. Revista Interdisciplinar de Gestão Social, 7(1), 15-37 . http:// doi.org/10.9771/23172428rigs.v7i1.24649 
Crusius, J., \& Mussweiler, T. (2012) When people want what others have: The impulsive side of envious desire. Emotion, 12(1),142-153. http://doi.org/10.1037/a0023523

De Mooij, M., \& Hofstede, G. (2002). Convergence and divergence in consumer behavior: implications for international retailing. Journal of retailing, 78(1), 61-69 . http://doi.org/10.1016/s00224359(01)00067-7

Elejalde-Ruiz, A. (2015). Millennial Workers Well-Dressed, Prone to Jealousy. The Detroit News. http://www.detroitnews.com/story/business/personalfinance/2015/05/17/millennial-workersdressed-prone-jealousy/27503285/

Ferrari, C. M. M., \& Gândara, J. M. (2015) Fotografias de viagens: replicando cenas da viagem perfeita em Curitiba/PR. Caderno Virtual de Turismo, 15(2), 112-130.

Festinger, L. (1954) A theory of social comparison processes. Human Relations, 7(2), 117-140. http:// doi.org/10.1177/001872675400700202

Goffman, E. (1956) The Presentation of Self in Everyday Life. London, UK.

Goffman, E. (1959) The Presentation of Self in Everyday Life. London, UK: Penguin.

Gössling, S., Scott, D., \& Hall, C. M. (2020). Pandemics, tourism and global change: a rapid assessment of COVID-19. Journal of Sustainable Tourism, 1-20. http://doi.org/10.1080/09669 582.2020 .1758708

Gumpo, C. I. V., Chuchu, T., Maziriri, E. T., \& Madinga, N. W. (2020). Examining the usage of Instagram as a source of information for young consumers when determining tourist destinations. SA Journal of Information Management, 22(1), 1-11. http://doi.org/10.4102/sajim.v22i1.1136

Hajli, N., Yichuan, W., \& Tajvidi, M. (2018). Travel envy on social networking sites. Annals of Tourism Research, 73, 184-189. http://doi.org/10.1016/j.annals.2018.05.006

Kerr, G., Lewis, C. \& Burgess, L. (2012). Bragging Rights and Destination Marketing: A Tourism Bragging Rights Model. Journal of Hospitality and Tourism Management, 19 (1), 7-14. http://doi. org/10.1017/jht.2012.17

Khanna, S. (2016). Don't Let Social Media Envy Drain Your Bank Account. Journal of Accountancy, Aug. http://www.journalofaccountancy.com/news/2016/aug/social-media-drives-spending-201615023. html

Krasnova, H., Spiekermann, S., Koroleva, K., \& Hildebrand, T. (2010) Online social networks: Why we disclose. Journal of Information Technology, 25(2), 109-125. http://doi.org/10.1057/JIT.2010.6.

Lee, S. Y. (2014). How do people compare themselves with others on social network sites?: The case of Facebook. Computers in Human Behavior, 32, 253-260. http://doi.org/10.1016/j.chb.2013.12.009

Lim, M., \& Yang, Y. (2015). Effects of Users' Envy and Shame on Social Comparison That Occurs on Social Network Services. Computers in Human Behavior, 51, 300-311. http://doi.org/10.1016/j. chb.2015.05.013

Lin, R., Ven, N. V., \& Utz, S. (2018). What Triggers envy on Social Network Sites? A Comparison Between Shared Experiential and Material Purchases. Computers in Human Behavior, 85, 271-281. http://doi.org/10.1016/j.chb.2018.03.049

Liu, H., Wu, L., \& Li, X. (2019). Social Media Envy: How Experience Sharing on Social Networking Sites Drives Millennials' Aspirational Tourism Consumption. Journal of Travel Research, 58(3), 355-369. http://doi.org/10.1177/0047287518761615 
BBR

18

314

Lo, I. S., \& McKercher, B. (2015). Ideal image in process: Online tourist photography and impression management. Annals of Tourism Research, 52, 104-116.

Lourenção, M., Giraldi, J. M. E., \& de Oliveira, J. H. C. (2020). Destination advertisement semiotic signs: Analysing tourists' visual attention and perceived ad effectiveness. Annals of Tourism Research, 84. http://doi.org/10.1016/j.annals.2020.103001

Machado, D. F. C. (2015). Fotografias de viagens nas redes sociais: um estudo sobre os efeitos da visualização de fotografias na imagem do destino e na intenção futura de visita (Tese de doutorado). Programa de Pós-Graduação em Administração, Universidade Federal do Rio Grande do Sul, Porto Alegre. http://bit.ly/2uRthSF

Marôco, J. (2010). Análise de equações estruturais: Fundamentos teóricos, software \& aplicaçôes. Report Number, Lda.

Spinoza (1999). Ethique. Trad. de Bernard Pautrat. Paris: Seuil. (Ed. bilíngue).

Marques, R. R. R., Cavalcante, C. E., \& Ferraz, T. V. (2017). “O Monstro de Olhos Esverdeados”: Gestão da Inveja em uma Organização Educacional. Revista de Administração, Contabilidade e Economia, 16(1), 283-304. http://doi.org/10.18593/race.v16i1.11531

Marujo, M. N. N. V. (2008). A Internet como novo meio de Comunicação para os testinos turísticos: o caso da Ilha da Madeira. Turismo em Análise, 19(1), 25-42. http://doi.org/10.11606/issn.19844867.v19i1p25-42

McCormic, E. (2018). Instagram is estimated to be worth more than $\$ 100$ Billion. https://www.bloomberg. $\mathrm{com} /$ news/articles/2018-06-25/value-of-facebook-s-instagram-estimated-to-top-100-billion

Menéndez, S. T., \& Vázquez, A. S. Virtual agents as a value creation tool in the era of C2C interactions. In. Gutiérrez, J. A. T., Casielles, R. V., Alonso, E. E., \& Mieres, C. G. (2017). Marketing Insights: la respuesta del comercio a las tendencias de comportamiento social del consumidor (October). Cátedra Fundación Ramón Areces de Distribución Comercial Universidad de Oviedo.

Mussweiler, T, Rüter, K., \& Epstude, K. (2006) The why, who, and how of social comparison: a social cognition perspective. In. Social comparison and social psychology: Understanding cognition, intergroup relations, and culture, 33-34, Cambridge University Press. http://doi.org/10.1017/ CBO9780511584329.004

Narangajavana Kaosiri, Y., Callarisa Fiol, L. J., Moliner Tena, M. Á., Rodríguez Artola, R. M., \& Sánchez García, J. (2019). User-Generated Content Sources in Social Media: A New Approach to Explore Tourist Satisfaction. Journal of Travel Research, 58(2), 253-265. http://doi. org/10.1177/0047287517746014

Parrot, W. G., \& Smith, R. H. (1993). Distinguishing the Experiences of Envy and Jealousy. Journal of Personality and Social Psychology, 64(6), 906-920. http://doi.org/10.1037//0022-3514.64.6.906

Parsons, H. (2017). 'Does social media influence an individual's decision to visit tourist destinations? Using a case study of Instagram', Bachelor of Arts dissertation in events, Cardiff Metropolitan University, Cardiff.

Pew Research Center. (2019) Social Media Fact Sheet. https://www.pewresearch.org/internet/factsheet/social-media/

Sabatini, F., \& Sarracino, F. (2019). Online social networks and trust. Social Indicators Research, 142, 229-260. http://doi.org/10.1007/s11205-018-1887-2 
Schlenker, B. R., \& Pontari, B. A. (2000). The strategic control of information: Impression management and self-presentation in daily life. In: A. Tesser, R. B. Felson, \& J. M. Suls (Eds.), Psychological perspectives on self and identity (p. 199-232). American Psychological Association. http://doi. org/10.1037/10357-008

Sheth, J. (2020). Impact of Covid-19 on Consumer Behavior: Will the Old Habits Return or Die? Journal of Business Research, 117, 280-283. doi: 10.1016/j.jbusres.2020.05.059

Souza, E. M., Montenegro, R. M. B., Quezado, I., \& Arruda, D. M. O. (2018). O sentimento de inveja suscitado pelo consumo de produtos turísticos divulgado no instagram. Revista Hospitalidade, 15(2), 60-82. http://doi.org/10.21714/2179-9164.2018v15n2.004

Suls, J.,\& Wheeler, L. (2000). Handbook of social comparison: Theory and research. Boston, MA: Springer US.

Taylor, D. G. (2020). Putting the "self" in selfies: how narcissism, envy and self-promotion motivate sharing of travel photos through social media. Journal of Travel and Tourism Marketing, 37(1), 64-77. http://doi.org/10.1080/10548408.2020.1711847

Taylor, D. G., \& Struttom, D. (2016). Does Facebook usage lead to conspicuous consumption? The role of envy, narcissism and self-promotion. Journal of Research in Interactive Marketing, 10(3), 231-248. http://doi.org/10.1108/JRIM-01-2015-0009

Van de Ven, N., Zeelenberg, M., \& Pieters, R. (2011). Why envy outperforms admiration. Personality and Social Psychology Bulletin, 37(6), 784-795. http://doi.org/10.1177/0146167211400421

Vecchio, R. P. (2000). Negative emotion in the workplace: Employee jealousy and envy. International Journal of Stress Management, 7(3), 161-179. http://doi.org/10.1023/A:1009592430712

Vogel, E. A., Rose, J. P., Roberts, L. R., \& Eckles, K. (2014). Social Comparison, Social Media, and Self-Esteem. Psychology of Popular Media Culture, 3(4), 206-22.

Wang, X.; Yu, C.; Wei, Y. (2012). Social media peer communication and impacts on purchase intentions: a consumer socialization framework. Journal of Interactive Marketing, 26(4), 198-208. http://doi.org/10.1016/j.intmar.2011.11.004

Wang, Y., Hsiao, S. H., Yang, Z., \& Hajli, N. (2016). The impact of sellers' social influence on the co-creation of innovation with customers and brand awareness in online communities. Industrial Marketing Management, 54,56-70. http://doi.org/10.1016/j.indmarman.2015.12.008

Whitty, M. T. (2008). Revealing the "real" me, searching for the "actual" you: Presentations of self on an internet dating site. Computers in Human Behavior, 24(4), 1707-1723. https://doi. org/10.1016/j.chb.2007.07.002

Wood, J. V. (1996). What is social comparison and how should we study it? Personality and Social Psychology Bulletin, 22(5), 520-537. http://doi.org/10.1177/0146167296225009

\section{Reference notes}

The authors developed a series of measures with several items, adopting scales previously validated in the existing literature adapted to the research context. The measures and studies on which they are based are: Social Comparison (Buunk \& Gibbons, 2006; Wang, Hsiao, Yang, \& Hajli, 2016); Travel Envy on Social Networks (Krasnova et al., 2010; Vecchio, 2000); Selfpresentation (Krasnova et al., 2010); and Intention to visit a destination (Chen, Shang, \& Li, 2014). 
BBR

18

316

\section{ADDITIONAL INFORMATION}

The authors declare not having conflict of interest

\section{AUTHORS' CONTRIBUTIONS}

DFCM: Conception of research, conceptualization, data curation, data analysis, supervision, writing of the original version, review and editing.

PCCS: Conceptualization, data collection, writing the original version, reviewing and editing. MLM: Conceptualization, data analysis, writing the original version, reviewing and editing. 